\title{
Døende pasienter i sykehjem: Sykepleiere gjør «mer av alt»og er «alene om alt»
}

Sykepleiere beskriver at sykepleie til døende i sykehjem krever «mer av alt», og de føler seg «alene om alt». Situasjonen må tas på alvor både organisatorisk og fagpolitisk.

\section{Forfattere}

\section{Sandra Jahr Svendsen}

Sykepleier og kreftkoordinator

Tjenestekontoret, Skedsmo kommune

\section{Bjørg Th. Landmark}

Sykepleier, rådgiver FoU og førstelektor

Utviklingsenheten: Skap gode dager, Drammen kommune og Institutt for sykepleievitenskap,

Høgskolen i Sørøst-Norge

\section{Ellen Karine Grov}

Professor

Institutt for sykepleie og helsefremmende arbeid, Høgskolen i Oslo og Akershus

\section{Nøkkelord}

\begin{tabular}{ll|l|l} 
Sykepleie Erfaring Terminalpleie Døende Sykehjem &
\end{tabular} 
Bakgrunn: Et økende antall dødsfall skjer i sykehjem. Det stiller store krav til sykehjemmet som arena for terminalpleie og til helsepersonellet som skal yte denne tjenesten. Derfor er det behov for mer kunnskap om hvordan sykepleiere erfarer at døende pasienter blir ivaretatt i sykehjem.

Hensikt: Hensikten med denne studien var å beskrive sykepleiernes erfaringer med døende pasienter i sykehjem. Forskningsspørsmålene setter søkelys på hva som er nødvendig for optimal behandling, pleie og omsorg ved livets slutt.

Metode: Tre fokusgruppeintervjuer med til sammen tolv sykepleiere genererte data. Vi benyttet kvalitativ innholdsanalyse som metodisk tilnærming.

Resultat: Sykepleiernes mål er å utøve faget slik at pasientene får optimal symptomlindring. I tillegg skal de ivareta pårørendes behov. Sykepleierne erfarer at kompleksiteten i pleie, omsorg og behandling av døende pasienter i sykehjem fordrer mer av alt, noe som innebærer betydelig kunnskap, ferdigheter og holdninger for å møte den døendes behov for lindrende behandling, pleie og omsorg. Funnene viser at sykepleierne ofte er «alene om alt» siden sykehjemmet har lav bemanning, og medarbeiderne har mangelfull sykepleiefaglig kompetanse. Det forventes at sykepleierne skal være dyktige klinikere, utøve lederskap samt gi råd og veiledning til pårørende og medarbeidere.

Konklusjon: Sykepleierne beskriver at sykepleie til døende i sykehjem krever «mer av alt», samtidig som de opplever å være «alene om alt». Opplæring av medarbeidere må prioriteres siden det er få tilsatte sykepleiere.

Antall dødsfall ved Norges 1000 sykehjem har vært økende de siste årene, og trenden fortsetter med om lag 48 prosent av alle dødsfall per år (1-3). De høye dødstallene stiller betydelige krav til sykehjemmet som arena for behandling, pleie og omsorg i livets sluttfase, og til helsepersonellet som skal yte tjenester til døende og deres pårørende $(2,4)$. I henhold til nasjonale retningslinjer (5) skal alle sykehjemsavdelinger gi tilbud som ivaretar pasientenes behov for grunnleggende lindrende behandling, pleie og omsorg, kalt palliasjon.

Pasienter med langtidsopphold i institusjon har i gjennomsnitt 6,5 diagnoser (7), og om lag 80 prosent av pasientene har kognitiv svikt (8). Ifølge Statistisk sentralbyrå er 76 prosent av pasientene på sykehjem 80 år eller eldre (6). Mange eldre har alvorlige kroniske lidelser. Det er behov for palliativ behandling og pleie av høy faglig kvalitet som følge av kompleksiteten i de gamles sykdomsbilder (5). 
Det er utfordrende å få pålitelige forskningsdata fra sykehjem om livets sluttfase. En av årsakene kan være høy turnover blant personalet, som bidrar til at frafallsprosenten i studier er stor (9). Andre årsaker kan være mangel på systematisk tilnærming og uklarhet i hvordan dokumentasjonen skal føres (10, 11). Det er behov for økt kunnskap om hvordan døende pasienters behov blir ivaretatt i sykehjem, både fra pasientens, de pårørendes og helsepersonellets perspektiv (2).

Sykepleiere har en særskilt rolle i arbeidet med døende pasienter og deres pårørende fordi de har døgnkontinuerlig oppfølging av pasientene og må håndtere komplekse problemstillinger knyttet til sykdom og konsekvenser av sykdom $(12,13)$. Det er derfor behov for mer kunnskap om sykepleiernes erfaringer. Hensikten med denne studien var å belyse sykepleiernes erfaringer med døende pasienter i sykehjem for å identifisere hva som er nødvendig for å kunne gi optimal behandling, pleie og omsorg ved livets slutt.

\section{Metode}

Studien hadde et kvalitativt eksplorativt og deskriptivt design. Vi benyttet fokusgruppeintervju som metode for å innhente data. Målet var å skape dynamikk i gruppen med oppfordring om å dele erfaringer og få frem ulike perspektiver om temaet (14). I fokusgruppeintervju fremkommer mangfoldige erfaringer som bidrar til at den enkelte deltakeren ser situasjoner i et nytt perspektiv, og ny forståelse blir utviklet $(15,16)$.

\section{Rekruttering og utvalg}


Førsteforfatter sendte ut skriftlig informasjon om studien til helse- og omsorgsledere i tre østlandskommuner. Alle de forespurte kommunene ønsket å delta. Førsteforfatter fikk en kontaktperson i hver kommune som videreformidlet informasjonen til respektive institusjonsledere, som igjen rekrutterte deltakere. Deltakerne underskrev samtykkeskjema, som ble sendt tilbake til førsteforfatter sammen med kontaktinformasjon.

Det viste seg å bli utfordrende å rekruttere tilstrekkelig antall informanter ut fra utvalgskriteriet om omfattende erfaring med døende. Vi ekskluderte sykepleiere fra spesialenheter ved sykehjem lindrende enheter og skjermete enheter for demens fordi bemanningsfaktoren er høyere enn ved ordinære sykehjemsavdelinger (5). Utvalget besto til slutt av tolv sykepleiere fra tre kommuner (tabell 1). De hadde gjennomsnittlig tolv års erfaring som sykepleiere, med en variasjon fra to til 31 år. Seks av sykepleierne hadde videreutdanning.

Tabell 1: Utvalg

$\begin{array}{lll}\text { Kjønn } & \begin{array}{l}\text { Antall år arbeidet } \\ \text { som sykepleier }\end{array} & \text { Eventuell videreutdanning } \\ \text { Kvinne } & 14 \text { år } & \text { Ingen videreutdanning } \\ \text { Kvinne } & 12 \text { år } & \text { Videreutdanning i aldring og eldreomsorg } \\ \text { Mann } & 15 \text { år } & \text { Kirurgisk og medisinsk sykepleie } \\ \text { Kvinne } & 31 \text { år } & \text { Videreutdanning i operasjonssykepleie } \\ \text { Kvinne } & 2 \text { år } & \text { Ingen videreutdanning } \\ \text { Kvinne } & 10 \text { år } & \text { Videreutdanning i sykepleiefaglig ledelse } \\ \text { Mann } & 10 \text { år } & \text { Ingen videreutdanning } \\ \text { Kvinne } & 17 \stackrel{a r}{ } & \text { Videreutdanning i palliasjon } \\ \text { Kvinne } & 9 \text { år } & \text { Videreutdanning i sykepleiefaglig ledelse } \\ \text { Kvinne } & 4 \text { år } & \text { Ingen videreutdanning } \\ \text { Kvinne } & 8 \text { år } & \text { Ingen videreutdanning } \\ \text { Kvinne } & 12 \text { år } & \text { Ingen videreutdanning }\end{array}$

\section{Datainnsamling}


Fokusgruppene besto av henholdsvis tre, fire og fem sykepleiere og ble gjennomført på deres arbeidssted. Førsteforfatter (moderator) gjennomførte intervjuene. Den assisterende moderatoren tok notater og observerte gruppedynamikken. Intervjuene ble tatt opp på lydbånd og deretter transkribert ordrett. Intervjuenes lengde var fra 55 til 70 minutter.

Vi benyttet en veiledende temaguide for å gi struktur på samtalen. Temaguiden tok utgangspunkt i hvordan døende pasienter blir ivaretatt i sykehjem slik det blir beskrevet av sykepleiere. Guiden ble utarbeidet med temaområder som fremkom på bakgrunn av litteraturgjennomgang og fra erfaringsbasert kunnskap. Alle tre forfatterne har lang klinisk erfaring innen palliasjon.

\section{Analyse}

Etter at vi hadde gjennomført fokusgruppeintervjuene, overførte vi lydfilene til datafiler og transkriberte dem. Transkripsjonen kan anses som et steg i analysen når forskeren etablerer et helhetsinntrykk og en struktur på dataene (17). Det var derfor aktuelt med en tematisk, tverrgående og datastyrt innholdsanalyse, som alle tre forfatterne deltok i.

I analysen var vi inspirert av Gadamers filosofiske hermeneutikk, der forståelsen står sentralt. Ved å forsøke å forstå teksten gir vi gyldighet til det saklige innholdet i teksten. Et hermeneutisk perspektiv inspirert av Gadamer (18) argumenterer for forståelsens «under» som resultat av deltakernes felles mening. Denne tilnærmingen ga føringer for fortolkningsprosessen som innebar en kontinuerlig frem- og tilbakeprosess mellom helheten og delene, og mellom delene og helheten. 
Førsteforfatter identifiserte meningsbærende enheter.

Disse enhetene ble kondensert til koder i en tabell for hvert fokusgruppeintervju. Videre analyserte vi på tvers av intervjuene. Vi sammenliknet kodene for å identifisere likheter og forskjeller, og deretter samlet vi dem i grupper som ble sortert i underkategorier og kategorier (17). For å sikre felles enighet og forståelse presenterte vi de meningsbærende enhetene for hver av forfatterne, som kodet og kategoriserte disse uavhengige av hverandre. Deretter møttes vi og drøftet frem til konsensus der vi var uenige (tabell 2). Drøftingen bidro til en fortolkning på et høyere abstraksjonsnivå. Resultater av analysen, underbygger syntesen slik den fremstilles i figur 1.

Tabell 2: Eksempel på analyseprosessen

\begin{tabular}{|c|c|c|c|}
\hline Meningsbærende enhet & Kode & Underkategori & Kategori \\
\hline $\begin{array}{l}\text { Omsorgen er jo å vise respekt og ta tid } \\
\text { både til pasienten og pårørende, og å } \\
\text { symptomlindre. Har pasienten smerte, } \\
\text { så gi smertestillende, er pasienten } \\
\text { kvalm, gi kvalmestillende, altså fore- } \\
\text { bygge mer ubehag. Det er siste fasen } \\
\text { og man må være til stede, observere } \\
\text { pasienten. Det er ikke bare å gi morfin } \\
\text { og gå ut, man skal være til stede og se } \\
\text { om morfinen har noen effekt. }\end{array}$ & $\begin{array}{l}\text { - Symptomkartlegging } \\
\text { - Vurdering av } \\
\text { symptomer } \\
\text { - Symptomlindring } \\
\text { - Oppfølging av } \\
\text { intervensjoner }\end{array}$ & $\begin{array}{l}\text { Kompetanse for å } \\
\text { møte pasientens } \\
\text { komplekse behov }\end{array}$ & $\begin{array}{l}\text { Roller og ansvar } \\
\text { i arbeidet med } \\
\text { terminale pasienter } \\
\text { i sykehjem }\end{array}$ \\
\hline
\end{tabular}

\section{Etiske overveielser}

Studien er godkjent av Norsk samfunnsvitenskapelige datatjeneste (NSD), referansenummer 38087. Sykepleierne fikk både muntlig og skriftlig informasjon, og de ga sitt skriftlige samtykke til å delta i studien. Vi opplyste om at de når som helst og uten begrunnelse kunne trekke seg. De fikk også informasjon om at personopplysningsskjemaet ble oppbevart innelåst, og at alle elektroniske filer var passordbeskyttet. Vi understreket at uttalelser ikke ville få konsekvenser for arbeidsforholdene til informanten. 
For å sikre trygghet og tillit også innad i fokusgruppen inngikk alle involverte en avtale om gjensidig taushetsplikt. Vi har fulgt forskningsetiske prinsipper slik de er nedfelt i Helsinki-deklarasjonen (19).

\section{Resultater}

Resultatene viste at kompleksiteten i pleie, omsorg og behandling av døende pasienter i sykehjem fordrer «mer av alt», noe som innebærer vesentlig kunnskap samt betydelige ferdigheter og holdninger. I tillegg viser funnene at sykepleierne ofte er «alene om alt», siden sykehjemmet har lav bemanning, og medarbeiderne har mangelfull kompetanse. Vi presenterer oppsummerte resultater i to kategorier med tilhørende underkategorier (tabell 3).

Tabell 3: Presentasjon med underkategorier og kategorier

\begin{tabular}{|c|c|}
\hline Kategori & Underkategori \\
\hline \multirow[t]{3}{*}{ Å ivareta den døende pasienten i sykehjem } & Å være til stede: observere, vurdere og handle \\
\hline & Å ivareta og involvere pårørende \\
\hline & Et ærefullt oppdrag - møtet med egne følelser \\
\hline \multirow{2}{*}{$\begin{array}{l}\text { Roller og ansvar i arbeidet med døende } \\
\text { pasienter i sykehjem }\end{array}$} & Kompetanse til å møte pasientens komplekse behov \\
\hline & Rammefaktorer \\
\hline
\end{tabular}

\section{Å ivareta den døende pasienten i sykehjem}

Resultatene viste at det å ivareta døende pasienter $\mathrm{i}$ sykehjem omfatter pasient, pårørende og sykepleier. Sykepleierne var opptatte av å være til stede hos den døende pasienten, noe de vurderte som en forutsetning for å kunne gi helhetlig pleie og behandling. Terminalpleie omfatter også avklaringer og planlegging som gjøres før pasienten er døende. I denne prosessen var pårørende en naturlig del. Resultatene viste at det kan være emosjonelt engasjerende og utfordrende å ivareta døende pasienter. Samtidig viste funnene at sykepleierne opplevde det som et ærefullt oppdrag å følge pasienten i den aller siste tiden, der de også møtte sine egne følelser og sin egen samvittighet. 


\section{三 «Sykepleierne opplevde det som et ærefullt oppdrag å følge pasienten i den aller siste tiden, der de også møtte sine egne følelser og sin egen samvittighet.»}

\section{Å være til stede: observere, vurdere og handle}

Sykepleierne beskrev tilstedeværelse som en forutsetning for å kunne ivareta pasienten gjennom kliniske observasjoner, vurderinger og iverksettelse av nødvendige tiltak:

«For å følge med på smerter, angst og alle symptomer kan man jo ikke bare være innom en sjelden gang.»

Resultatene viste at det ikke alltid er like enkelt å vurdere når en pasient er døende, og at sykepleiernes vurderinger ikke alltid er sammenfallende:

«Jeg opplever noen ganger at jeg får rapport om at pasienten er døende, og når jeg kommer inn til pasienten, så tenker jeg 'hmm, er han egentlig det?'. Jeg tror vi legger litt forskjellig i når terminalfasen starter.»

\section{«Terminalpleie er mer av alt.»}

\section{Fokusgruppedeltaker}

Den døende pasienten i sykehjem har komplekse behov som tilsier tett oppfølging fra sykepleier, som kan observere, vurdere og iverksette ulike lindrende tiltak. En sykepleier sa det så treffende:

«Terminalpleie er mer av alt.»

\section{Å ivareta og involvere pårørende}


Sykepleierne omtalte ofte pasient og pårørende under ett, noe som understreker at sykepleierne ser hvor viktig det er å inkludere pårørende i avklaringer og planlegging før pasienten er døende. Sykepleierne sa at slik involvering krever målrettet informasjon, og informasjonen må dessuten ofte gjentas. De fortalte at flere pårørende ønsket å være til hjelp og gjøre noe mer enn bare å sitte ved sengekanten:

«Jeg tror det skaper veldig tillit hvis de får være med. Jeg kan for eksempel vise dem hvordan de kan gjøre munnstell, så de får gjort noe når pasienten ikke spiser og drikker lenger. Jeg tror at det hjelper mye, de får delta på det som skjer.»

Samtidig sa flere sykepleiere at det var viktig å trygge pårørende med at det er viktig bare å vcre hos den døende. Sykepleierne var enige i at det var viktig å bekrefte pårørende for den de er og det de gjør. Pårørendes behov er ofte ulike; noen trenger tett oppfølging og mye tilstedeværelse fra sykepleier, mens andre synes det er greit å være alene med tilsyn innimellom. Sykepleierne erfarte at deres tilgjengelighet har innvirkning på pårørendes trygghet med å være hos pasienten, men at de må tydeliggjøre at de tar ansvaret:

«Hvis du ser at pasienten er urolig, og du må gi medikamenter, så er det ikke bare å gi og gå, da må du følge det opp. Samme om pårørende sitter der eller ikke, det er din oppgave.»

\section{Et ærefullt oppdrag - møtet med egne følelser}

Det kan være emosjonelt engasjerende å ivareta døende pasienter, noe som påvirker samvittighet og følelser. Flere sa det opplevdes ærefullt å få lov til å følge pasienten det aller siste stykket av livet. Samtidig uttrykte de at det kan være overveldende å ha så mye ansvar for en person de siste timene og dagene av livet: 
«Jeg føler noe ekstra for dem, for de er veldig

hjelpeløse. Tenker at de ikke lenger har noen stemme

eller noen krefter til å gjøre noe som helst, de er veldig

overgitt i våre hender. Så det er ærefullt, og det er en

spesiell situasjon, man inntar på en måte en litt annen

del av sykepleierrollen.»

\section{三 «Sykepleierne fortalte at det kan være en påkjenning å være personlig engasjert i møte med den døende.»}

Sykepleierne fortalte at det kan være en påkjenning å være personlig engasjert i møte med den døende. De beskrev et felles ønske om at pleien til den døende pasienten skal være av ypperste kvalitet:

«Man gir alt man har når man har omsorg for noen som skal dø. Da ligger jeg og tenker på det etterpå og evaluerer meg selv: 'Har jeg sagt de riktige tingene? Gjorde jeg alt jeg kunne for at de hadde godt leie? Hadde jeg gode hender?' Jeg tar det veldig alvorlig.»

Sykepleierne har ulike meninger om å bli følelsesmessig engasjert:

«Jeg har empati, men jeg mener at når jeg har gjort den jobben, så er alt ferdig. Pasienten og pårørende er tatt farvel med. Da tenker jeg ikke på den pasienten, selv om jeg er i begravelse etterpå, da viser jeg respekt for pasienten og for pårørende, men det berører meg ikke.»

\section{Roller og ansvar i arbeidet med døende pasienter i sykehjem}


Sykepleierne fremhevet kompetanse som en

forutsetning for å føle seg trygge i egen rolle, både når det gjaldt å håndtere pasientens behov, ivareta den koordinerende funksjonen og samhandle med andre yrkesgrupper. Sykepleierne reflekterte over sin egen rolle i systemet og hva de kan påvirke. De reflekterte også over hva som administreres på et høyere nivå utenfor deres kontroll.

\section{Kompetanse til å møte pasientens komplekse behov}

Dataene viste at kompetanse handler om faglig trygghet samt evne til å gjøre vurderinger og bringe informasjon videre. Resultatene viste at det er høyst individuelt hva sykepleierne opplever som trygt, for eksempel når det gjelder legemiddelhåndtering. Noen leger forordner «inntil smertelindring», noen skriver «mg inntil x 6, kan økes ved behov til ...», mens andre skriver «mg x 4» på medisinkortet. Flere sykepleiere uttrykte at det er trygt når det er forordnet en maksdose.

For andre sykepleiere var det en større trygghet å kunne gi så mye det var behov for for å lindre pasientens plager, slik at de ikke trengte å bruke tid på å kontakte lege flere ganger for ny dosering. De var enige om at klare rutiner og forordninger av legemidler til å lindre plagsomme symptomer er en forutsetning for å ivareta den døende pasienten.

Sykepleierne understreket flere episoder der de har måttet forhandle seg frem til forordninger av nødvendige legemidler:

«Noen er veldig tilbakeholdne, og nesten rett og slett så du må forhandle ordentlig hardt for å bli trodd på status. Det synes jeg er veldig slitsomt.»

\section{Rammefaktorer}

Sykepleierne trakk frem organisatoriske faktorer som er utenfor deres kontroll, eksempelvis bemanningsfaktor og fagdekning: 
«På sykehuset har de fire-fem sykepleierkollegaer og fire-fem leger som du kan konferere med. Får du ikke stukket en veneflon, kommer en anestesisykepleier og gjør det for deg. Det gjør de ikke her. Her må du ta avgjørelsen og valgene selv. Du må høre med en lege, og han kommer kanskje om noen timer.»

\section{三 «Her må du ta avgjørelsen og valgene selv. Du må høre med en lege, og han kommer kanskje om noen timer.»}

\section{Fokusgruppedeltaker}

De uttrykte frustrasjon over å bli dratt i ulike retninger når det er mange oppgaver, roller og ansvar som skal ivaretas:

«Jeg har vært alene sykepleier på 100 pasienter ... Og du har to til tre døende ... Du har fire til fem pårørende på hver pasient, og du skal fange opp alt sammen.»

\section{Mer av alt og alene om alt - en syntese av studiens resultater}

Sykepleiere beskrev arbeidet med døende som faglig, personlig og organisatorisk komplekst, som «mer av alt», og at de ofte er «alene om alt». Dette arbeidet innebærer at sykepleierne har mer oppmerksomhet på pasientens komplekse behov og utviser større emosjonelt engasjement, samt at de pårørende er mer involvert. Kompleksiteten krever kunnskap og erfaring på individnivå og systemnivå. 
Figur 1 illustrerer kategoriene som fremkom gjennom analysen av det empiriske materialet i denne studien. Funnene viser at elementene i figuren påvirker hverandre gjensidig. For eksempel er det vanskelig å gi en forsvarlig og helhetlig tjeneste (systemnivå) uten å inkludere pasienten og dens pårørende (individnivå), som er enheten for tjenesten etter definisjonen av palliasjon (21). Gjennom analysen fremsto sykepleiernes erfaringer med døende pasienter i sykehjem som flere prosesser som gjensidig påvirker hverandre i et dynamisk samspill, som både omhandler den enkelte sykepleier (individnivå), samspillet med kollegaer og de ytre rammene (systemnivå).

Figur 1: En syntese av studiens resultater

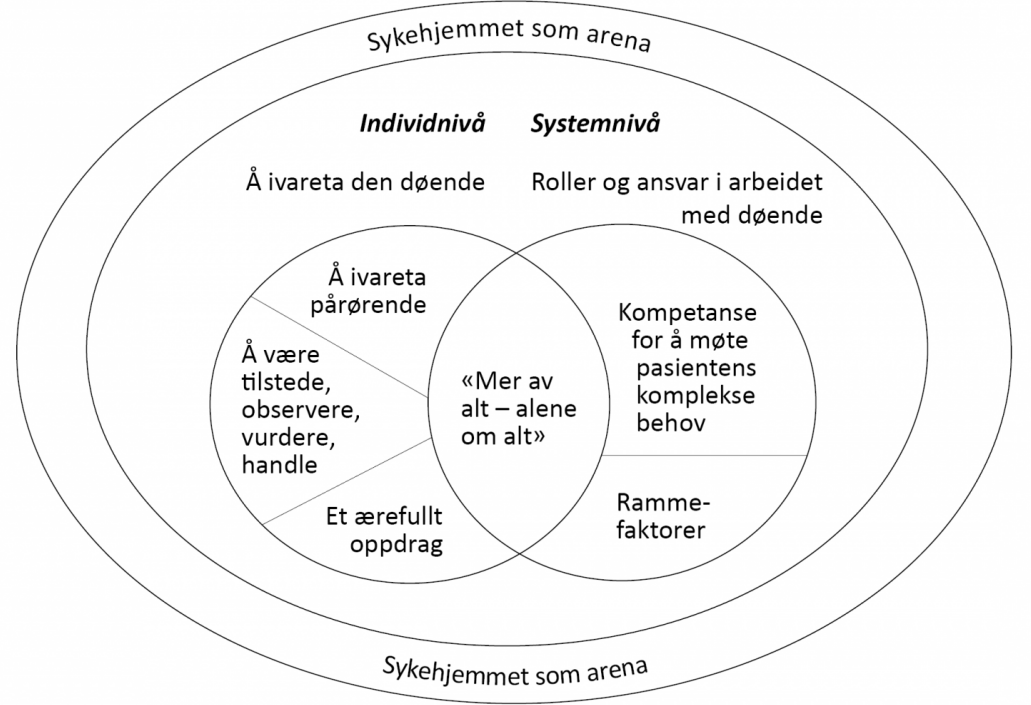

\section{Diskusjon}


Hensikten med studien var å identifisere sykepleiernes erfaringer med hva som er nødvendig for optimal behandling, pleie og omsorg ved livets slutt. Resultatene viser at sykepleierne har en rekke funksjoner og roller å ivareta, både på individ- og systemnivå. På individnivå mener sykepleierne at det er sentralt å kunne være til stede hos den døende og gjøre observasjoner, foreta vurderinger og handle for å lindre pasientens plager.

Funnene viser at sykepleierne er opptatte av å involvere og ivareta de pårørende. I tillegg beskriver de omsorgen for den døende som et ærefullt oppdrag hvor de møter egne følelser som må bearbeides og håndteres. Tidligere forskning viser at det er utfordringer knyttet til arbeidet med døende pasienter i sykehjem. Gjerberg og medarbeidere (21) fant blant annet at manglende ressurser og kompetanse kan resultere i etiske utfordringer, mens Flo og medarbeidere (10) avdekker manglende systematikk ved tilnærming overfor døende samt ufullstendig dokumentasjon.

\section{Arefullt å ivareta døende og pårørende}

Funnene i studien vår viser at det er utfordrende å være til stede når pasienten er døende. Pasienten har komplekse behov som krever tett oppfølging. Sykepleierne uttrykker at de kan ha ulike oppfatninger av samme situasjon. Samtidig beskriver de et ønske om at pleien til den døende skal være av ypperste kvalitet. Andre studier dokumenterer at helsepersonell har et genuint ønske om at den døende skal få en god død, og at pleierne strekker seg langt for å etterkomme pasientens og pårørendes ønsker (22-24).

\section{三 «Det er utfordrende å være til stede når pasienten er døende.»}


Sykepleierne trekker frem betydningen av å ivareta og involvere pårørende, noe som understøttes av studien til Davies og Steele (25). Det fremkommer i studien deres at det kan føles overveldende samtidig som det er givende å sitte ved dødsleiet til en nærstående. Det kommer også klart frem i studien til Dreyer (26) at pårørende har behov for å bli ivaretatt. Thoresen og medarbeidere (27) fremhever også viktigheten av å være til stede gjennom fellessamtaler for å fremme god palliasjon.

I vår studie omtales tilstedeværelsen hos pasient og pårørende som «et ærefullt oppdrag». Sykepleierne beskriver det som emosjonelt engasjerende. På samme tid formidler de at det kan være overveldende med så stort ansvar. Også andre studier har dokumentert sykepleiernes bekymringer for at de ikke gjør nok i møte med døende $(21,22)$.

\section{Mangelfull legedekning gir mer ansvar til sykepleierne}

Resultatene viser at det kan være problematisk for sykepleierne når det er vanskelig å få tak i lege og det er få leger å få tak i, og når det er uavklarte ansvarsforhold mellom lege og sykepleier. Legedekningen ved norske sykehjem er mangelfull (28). I dag er det ett legeårsverk per 130 pasienter i sykehjem. Til sammenlikning er det én lege per 1,3 pasient på sykehus (28). Å vite når lege skal kontaktes, krever vurderingskompetanse og kunnskaper om symptomlindring. 
Disse funnene støttes av Marshall og medarbeidere (29), som viser at helsepersonell erfarer at lege ofte er utilgjengelig, og at sykepleiere må ta viktige avgjørelser uten kompetent personell å diskutere med. Ifølge Hov og medarbeidere (22) mente noen sykepleiere at de hadde kunnskap om pleie av alvorlig syke og døende pasienter som ikke ble tatt hensyn til i diskusjoner med legen. Hov og medarbeidere fortalte om situasjoner der de måtte forhandle seg frem til forordninger for å kunne lindre pasientens symptomer. Dette synliggjør behovet for kontinuerlige avklaringer med legen, noe som kan være en utfordring å få til i sykehjemmet.

\section{Utfordrende for sykepleierne å ha overordet} ansvar

Funnene i studien vår viste at sykepleiernes

koordinerende funksjon overfor annet helsepersonell, både faglært og ufaglært, er en del av arbeidshverdagen deres. I sykehjem er 30 prosent av medarbeiderne uten formell utdanning (30). Det medfører at sykepleierne har en særskilt utfordrende funksjon da de har det overordnete ansvaret for sykepleietjenesten, både faglig (individnivå) og organisatorisk (systemnivå). Oppgaver må selvsagt delegeres, men ifølge Orvik (31) kan ikke alle oppgaver delegeres videre. 
I rapporten «Underbemanning er selvforsterkende» (4) poengteres det at mangel på sykepleiere i sykehjem går ut over kvaliteten på tjenestene og arbeidsmiljøet til de ansatte. Det er behov for kompetanse både på individnivå: å ivareta den døende i sykehjem, og på systemnivå: roller og ansvar i arbeidet med døende pasienter i sykehjem. Sykepleiernes erfaringer, slik det fremkommer i studien vår, viser at behovet for «mer av alt» og det ikke å være «alene om alt» må tas på alvor organisatorisk og fagpolitisk. Landsdekkende kartleggingsstudier av sykepleieres erfaringer og konsekvenser for sykepleierutdanningen er viktige fremtidige forskningsområder. Sykehjemmet som arena for forskning bør også prioriteres.

\section{Studiens styrker og svakheter}

En styrke ved studien er at informantene er sykepleiere som har mange års erfaring med palliasjon i sykehjem, og flere av sykepleierne har videreutdanninger. Fokusgruppeintervjuene bar preg av dynamikk informantene imellom, som bidro til at temaet ble belyst fra mange sider.

En begrensning ved studien er at kun to mannlige sykepleiere deltok, men denne kjønnsfordelingen er representativ for norske sykehjem. Datamaterialet er forholdsvis lite, men de tre fokusgruppeintervjuene har gitt rikholdige data. Vi har prøvd å sikre påliteligheten av funnene ved å følge trinnene i analysen av data. Vi har brukt sitater for å vise troverdigheten i resultatene (20).

\section{Konklusjon}


Sykepleierne uttrykker at sykepleie til døende i

sykehjem krever «mer av alt». I tillegg opplever de å være «alene om alt». Det er forventet at sykepleierne skal være dyktige klinikere og utøve lederskap, gi råd og veiledning til pårørende og medarbeidere. I tillegg skal de reflektere over egen praksis i lys av holdninger og verdier. Studien belyser hvordan rammefaktorer som bemanning og kompetanse har innvirkning på sykepleiernes funksjon og ansvar.

Sykepleiernes klare målsetting er å utøve faget slik at pasientene får optimal symptomlindring. Denne målsettingen ivaretas ved at sykepleierne behersker klinisk vurderingskompetanse og kan iverksette relevante tiltak. I tillegg ivaretar de pårørendes behov. Tverrfaglig samarbeid og opplæring av medarbeidere kan synes krevende siden det er liten tilgang på legetjeneste i sykehjem og få sykepleiere som arbeider i sykehjem.

\section{Referanser}

1. Statistisk sentralbyrå. Tabell: 09929: Helse- og omsorgsinstitusjonar, etter eigarforhold. 2015.

Tilgjengelig fra:

https://www.ssb.no/statistikkbanken/SelectVarVal/Define.asp?

MainTableHelsOmsInst\&KortNavnWeb-

pleie\&PLanguage $=0$ \&checkedtrue (nedlastet 31.10.2016).

2. $\quad$ Meld. St. 29 (2012-2013). Morgendagens

omsorg. Oslo: Helse- og omsorgsdepartementet; 2013.

3. Statistisk sentralbyrå. Dette er Norge 2014.

Hva tallene forteller. Oslo: Statistisk sentralbyrå; 2014.

4. Gautun H, Øien H, Bratt C. Underbemanning er selvforsterkende. Konsekvenser av mangel på sykepleiere i hjemmesykepleien og sykehjem. NOVArapport; 6/2016. 
5. Helsedirektoratet. Nasjonalt handlingsprogram med retningslinjer for palliasjon i kreftomsorgen. Oslo: Helsedirektoratet; 2015.

6. Mørk E. Kommunale helse- og omsorgstjenester 2014. Statistikk om tjenester og tjenestemottakere. Rapport 2015/42. Statistisk sentralbyrå. Tilgjengelig fra: https://www.ssb.no/helse/artikler-ogpublikasjoner/_attachment/242516?_ts=150606744c0 (nedlastet 06.11.2016.)

7. Trier EL, Jørstad C. Munnstell av alvorlige syke. Sykepleien. 2014(9):58-61. Tilgjengelig fra: https://sykepleien.no/forskning/2014/06/munnstell-avalvorlig-syke (nedlastet 04.09.2017).

8. Bergh S, Holmen J, Saltvedt I, Tambs K, Selbæk G. Demens og nevropsykiatriske symptomer hos sykehjemspasienter i Nord-Trøndelag. Tidsskrift for Den norske legeforening. 2012(132):1956-9.

9. Tilden VP, Thompson SA, Gajewski BJ, Buescher CM, Bott MJ. Sampling challenges in nursing home research. Journal of the American Directors Association. 2013;14(1):25-8.

10. Flo E, Husebo B S, Bruusgaard P, Gjerberg E, Thoresen L, Lillemoen $\mathrm{L}$ et al. A review of the implementation and research strategies of advanced care planning in nursing homes. BMC Geriatrics. 2016;16(24). DOI: 10.1186/s12877-016-0179-4.

11. Haugen DF, Iversen GS, Huurnink A. Hvordan kan behandlingsplaner være til nytte den siste tiden av pasientens liv? Omsorg. 2015;2:29-33.

12. Haugan G. The relationship between nursepatient interaction and meaning-in-life in cognitively intact nursing home patients. J Adv Nurs. 2014;70(1):107-20. DOI: 10.1111/jan.12173. 
13. Johnson S, Bott MJ. Communication with residents and families in nursing homes at the end of life. J Hosp Palliat Nurs. 2016;18(2):124-30. DOI: 10.1097/njh.0000000000000222.

14. Malterud K. Fokusgrupper som forskningsmetode for medisin og helsefag. Oslo: Universitetsforlaget; 2012.

15. Morgan DL. The focus group guidebook: Focus group kit 1. Thousand Oaks, California: Sage Publications; 1998.

16. Krueger RA. Focus groups. A practical guide for applied research. Thousand Oaks, California: Sage Publications; 1994.

17. Kvale S, Brinkmann S. Det kvalitative forskningsintervju. 2. utg. Oslo: Gyldendal Akademisk; 2009.

18. Gadamer HG. Forståelsens filosofi. Utvalgte hermeneutiske skrifter. Oslo: J.W. Cappelens Forlag; 2003.

19. World Medical Association. WMA Declaration of Helsinki - Ethical principles for medical research involving human subjects. Tilgjengelig fra: https://www.wma.net/policies-post/wmadeclaration-of-helsinki-ethical-principles-for-medicalresearch-involving-human-subjects/ (nedlastet 31.10.2016).

20. Graneheim UH, Lundman B. Qualitative content analysis in nursing research: concepts, procedures and measures to achieve trustworthiness. Nurse Education Today. 2004;24:105-12. DOI: 10.1016/j.nedt.2003.10.001.

21. Gjerberg E, Førde R, Pettersen R, Bolling G. Ethical challenges in the provision of end-of-life care in Norwegian nursing homes. Social Science \& Medicine. 2010;71(4):677-84. 
22. Hov R, Athlin E, Hedelin B. Being a nurse in nursing home for patients on the edge of life.

Scandinavian Journal of Caring Sciences.

2009;23(4):651-9.

23. Percival J, Johnson M. End-of-life care in nursing and care homes. Nursing Times.

2013;108(1/2):20-3.

24. Wallerstedt B, Andershed B. Caring for dying patients outside special palliative care settings: experiences from a nursing perspective. Scandinavian Journal of Caring Sciences. 2007;21(1):32-40.

25. Davies B, Steele R. Supporting families in palliative care. I: Ferrel BR, Coyle N (red.). Oxford Textbook of Palliative Nursing. New York: Oxford University Press; 2010 (s. 613-28).

26. Dreyer A. End-of-life decision-making in nursing homes. A qualitative study. Upublisert manuskript. Medisinsk fakultet, Universitetet i Oslo; 2012. Tilgjengelig fra: https://www.duo.uio.no/bitstream/handle/10852/28029/dravhandlingdreyer.pdf?sequence=3 (nedlastet 31.10.2016).

27. Thoresen L, Ahlzén R, Solbrække KN. Advance care planning in Norwegian nursing homes Who is it for? J Aging Stud. 2016;Aug(38):16-26. DOI: 10.1016/j.jaging.2016.04.003.

28. Flo E, Husebø BS. Kvalitet og kompetanse på sykehjem - behov for en standard for behandling og omsorg. Omsorg - Nordisk tidsskrift for palliativ medisin. 2015;(1):5-9.

29. Marshall B, Clark J, Sheward K, Allan S. Staff perceptions of end-of-life care in aged residential care: A New Zealand perspective. Journal of Palliative Medicine. 2011;14(6):688-95. 
30. Meld. St. 10 (2012-2013). God kvalitet trygge tjenester. Oslo: Helse- og omsorgsdepartementet; 2013.

31. Orvik A. Organisatorisk kompetanse - i sykepleie og helsefaglig samarbeid. Oslo: Cappelen Damm Akademisk; 2004. 